\title{
Ownership of human genes
}

SIR - Ownership by capture is an elementary principle in English and American law. Where ownership in a thing does not already exist, legal title is awarded to the person who is first in time to possess it. This rule has been liberally and zealously applied, giving the captor of the undomesticated animal and the extractor of natural waters good title against all the world. It is inevitable that this same canon of the law should find its way to the genes (Nature 381, 11-14; 1996). Who else should own the gene but the scientist who first captures it by cloning?

In an early American lawsuit, Post took Pierson to court in New York for interfering with his right to a wild fox. Pierson had intercepted Post in pursuit of a fox, killed it, and carried off the bounty for himself (Pierson v. Post, Supreme Court of New York, 1805, 3 Cai. R. 175, 2 Am. Dec. 264; J. Dukeminier \& J. E. Krier, Property, Little, Brown, pp 15-19; 1988). The court, relying on English and Roman law, wrote that Pierson as the captor had good title to beast ferae naturae, wild and free. Until its status was changed by Pierson's dominion over it by actual possession, the fox was available and unowned. The court, for policy reasons, judged that the fox was a pest to farmers so it was for the good of society that fox hunting be encouraged. Capture as ownership made the outcome of hunting events more certain.

In later suits about property rights of natural resources, the wild and migratory nature of underground water, gases and oil evoked the image of Post's fox. Courts adopted the analogy, and possession, again, became the touchstone of ownership. It made sense to modern jurists considering the increased value of the thing ferae naturae once it had been captured and reduced to possession.

Genes, like wild animals and underground waters, are a wandering, flowing resource, acted on by the physical forces of nature. Individuals in a species are linked by their genes. There is a recurrent exchange of genes between populations and the individuals who comprise the populations. The sum of all the genes of the species is the gene pool. Much as the Earth stores water for human consumption, the gene pool preserves the population's genes for future times. It is a genetic repository. If, for example, as a result of a sudden environmental change or the appearance of a new parasite, a formerly neutral allele were to confer a benefit on individuals having it, the frequency in the population of the allele would increase, as it flowed from the gene pool to the individual.

A gene's status in nature is no different from the wild beast or migratory waters. Until cloned, it is gene ferae naturae. The value is in its taking. Gene hunting should be encouraged for policy reasons, because it leads to research and development of products that enhance public health.

Ownership by cloning is reasonable. The alternative would be too uncertain. A claim by one person to one gene as it exists on his chromosome is likely to be contested by another who believes he is the owner because it exists on his chromosome. At the very least, siblings will share some of the same genes and thus will be forced to battle among themselves as to who is the rightful owner. Moreover, even if siblings had a common goal and were willing to settle on joint ownership, the controversy would not end there. Shared genes, of course, extend in all directions, familial, geographical and temporal. As they exist on chromosomes, genes cannot be considered personal property. If gene ownership were decided by who in the population had a chromosome having a particular allele in the gene pool, who would get paid? Only those who have it? Or all contributors to the gene pool as conservators of the genetic material? Can you buy the right to a gene in future offspring?

\section{Richard M. Lebovitz}

Milen, White, Zelano, \& Branigan,

Arlington Courthouse Plaza I,

2200 Clarendon Boulevard, Suite 1400 ,

Arlington, Virginia 22201, USA

e-mail: Lebovitz@MWZB.com

SIR - The Commentary article by Thomas et al., "Ownership of the human genome" (Nature 380, 387-388; 1996), is valuable, but the interpretation of the findings should be approached with caution.

Patents do not confer "ownership of the human genome" in an expansive sense to an individual or organization; rather, they provide a legally enforceable exclusive right to make, sell or use the patented invention for a limited period. With this in mind, we are undertaking an analysis of US patents, starting from a base of 1980-93 patents selected by the US Patent and Trademark Office for the congressional Office of Technology Assessment (OTA). This database was turned over to the Kennedy Institute of Ethics at Georgetown University in Washington DC so that the institute could catalogue the collection and make the patents available to the public. The institute plans to update, catalogue and begin to analyse the database and expand it to include foreign patents.

This collection of patents was also selected to identify "human DNA sequence patents", but we have found in our preliminary analysis that only a few patents produced by a simple database search strategy correspond to what most molecular biologists would regard as human genes or even parts of the human genome. Some of the most important and valuable such patents are for genes and gene products - enzymes, peptide hormones, receptors and other obviously relevant macromolecules. But many patents cover production methods, research methods, veterinary vaccines based on traditional biology, sperm and oocyte selection methods, and even peptides that contain the word 'gene' in their name for historical reasons but lack claims to DNA sequences or genes. A large number of the patents captured by a search that combines 'gene' and 'human', 'DNA' and 'human' or 'human' plus a DNA genetic initiator string ('AUG' or 'ATG') capture genes from any organism as well as some peptide and methods patents. It would be useful if authors specified how they defined "patented human DNA sequences".

Moreover, the real work of patents what limits others' rights - is done in their claims, not what is disclosed about the invention. We are attempting to categorize more precisely the nature of DNA-based inventions and the scope of their patent claims, to enable more refined analysis of patent subcategories. It might be useful, for example, to identify and compare only those patents that claim full-length genes.

Differences in patent strategy can also make patent counts misleading. Many patent applications filed first in the United States, for example, contain numerous broad claims. The Amgen patent for erythropoietin, arguably the most valuable human DNA patent so far, is quite long and has dozens of broad claims for the genecontaining vector, use of the gene, production and use of the gene product, and cells transformed by the vector (the corrections alone run to more than 40 pages). A betainterferon patent, in contrast - first filed in Japan on behalf of Kyowa Hakko Kogyo contains only a single claim for the expression vector, with no claims about the gene product, the transformed cell lines, or uses of the gene product or vector. Yet both patents are counted equally if the only index is patents issued. A broad patent of the former type thus might cover an expanse of intellectual property comparable to that of five or six narrower ones, as Thomas et al. point out.

This is not a minor problem, but one that can severely warp interpretation of patent counts, as the differences in scope among patents are demonstrably large, and differ systematically. This problem is quite severe when comparing patent applications initiated in the United States to those originating in Japan. Raw patent counts can be analytically useful, but must be treated with caution, and in the case of DNA-based patents, analysis of patents grouped for similarity in the scope of claims and subject matter may be required.

Finally, the financial value of patents 
$\checkmark$ appears extremely variable. Multi-billiondollar biotechnology patents, such as the Amgen patent for erythropoietin and the Genentech patents on tissue plasminogen activator, are the rare exceptions and not the rule. Even patents of intermediate value, such as those covering broadly useful research and production methods are unusual (for example, the Cohen-Boyer patents for recombinant DNA, the Caltech and Applied Biosystems patents on automated DNA sequencing and pertinent chemistry, or the Cetus patents on polymerase chain reaction). Most patents appear to have vastly less cash income value, and many seem unlikely to tap into large commercial markets at all. When analysing commercial uses of genome research, one cares mainly about the most economically valuable patents, or patents that might constrain research, improvements, and development by others - such as those covering broadly applicable research methods or macromolecules relevant to research with diverse applications.

Robert Mullan Cook-Deegan

National Academy of Sciences, 2101 Constitution Avenue NW,

Washington, DC 20418, USA

LeRoy Walters

Doris Goldstein

Stephen McCormack

Kennedy Institute of Ethics and National

Reference Center for Bioethics Literature,

Georgetown University,

Washington, DC 20057, USA

\section{Cost of living in domed cities}

SIR - Perhaps the most important result of the first Biosphere-2 experiment was the documentation of the extremely high cost of providing nature's free life support services with the use of non-renewable fossil fuels ${ }^{1}$. Now that data on the energy consumption during the two-year closure (1991-93) have been published, the monetary cost can be calculated.

Electricity required to maintain a habitable environment artificially for two years was consumed at a rate of $700 \mathrm{~kW}$ and natural gas at the rate of 23 million $\mathrm{kJ}$ per hour (ref. 2). In units that utility companies use to calculate our bills, consumption for the two-year period comes to 12.5 million $\mathrm{kW}$ hours $(\mathrm{kWh})$ of electricity and 3.8 million therms of gas. At 10 cents per $\mathrm{kWh}$ and 70 cents per therm (average rates in the United States), the costs would be $\$ 1.25$ million and $\$ 2.6$ million respectively, or approaching $\$ 4$ million altogether. (The underwriters of the Biosphere- 2 experiment did not actually have to pay this much in dollars because they had their own power plants and could produce energy at commercial rates.) If the crew of 8 people had to pay the utility bills at these residen- tial rates, their monthly bill would be more than $\$ 150,000$. At anywhere near this cost, very few of the billions of people on Earth could ever afford to live in domed cities.

Not all but a good portion of this energy cost can be considered as replacing the lifesupport services involved in the Earth's solar-driven atmospheric and hydrological cycles for which we pay little or no money. Most of the electricity, for example, was consumed in operating the complex pumping and filtering machinery (both inside the enclosure and in the outside accessory 'lungs' and cooling towers) that circulated the air, maintained its pressure and recycled and cleaned all the water. Much of the natural gas was expended in heating and cooling the living space. The cost of electricity and gas is, of course, only the tip of the iceberg of the millions of dollars that have already been spent in building the complex and will be spent maintaining the complex engineering in the future.

Some scientists have been critical of the first Biosphere- 2 experiment as not being "real science" because the crew were not scientists, but people trained and selected for their ability to work together, grow all their own food, monitor and manage the plant and animal life, record oxygen levels and other vital necessities, man the pumps and engineering control devices, and especially for their willingness to live at a subsistence level for two years. Very few specialized scientists could qualify for such a job.

In a recent report ${ }^{3}$, the crew estimated that they spent about $45 \%$ of their waking hours growing and preparing food, $25 \%$ in maintenance and repair, $20 \%$ in communication (inside and with the outside) and 5\% in carrying out small research projects, which left little time for relaxation and recreation. I happened to be present soon after the biospherians emerged from their two-year isolation and were being interviewed by the press. Someone enquired about their personal lives while inside and I heard one of the crew exclaim: "Look, we were so busy just trying to survive that we didn't have any time for hanky-panky". As with the Apollo-13 flight to the Moon, survival becomes the mission when life-support is in question.

The fact that the eight people emerged still speaking to each other and healthier than when they went in is, in itself, quite an accomplishment. Viewed as an exercise in human ecology, life-support science (biospherics) and environmental engineering, the experiment, in my opinion, was a considerable success.

Eugene P. Odum

Institute of Ecology,

University of Georgia,

Athens, Georgia 30602-2202, USA

1. Macilwain, C. Nature 380, 275 (1996)

2. Dempster, W. F. Society for Automotive Engineers tech. pap. ser. 932290 (Warrendale, Pennsylvania, 1993)

3. Nelson, M. \& Dempster, W. F.(unpublished results.)

\section{Less rosy view of science funding}

SIR - My view of science funding in the United States is neither as optimistic nor as complimentary to President Bill Clinton as Nature's (381, 1; 1996). Although Congress has generally supported funding of investigator-initiated academic research, the president repeatedly emphasizes the federal government's own "critical role to play" in carrying out and directing research and development. Moreover, he derides the budget-cutters when they find needed funding by trimming ineffective technology programmes at the Department of Commerce and the Environmental Protection Agency (EPA).

While small increases in Clinton's budget for fiscal year 1997 appear to keep the National Institutes of Health (NIH) and the National Science Foundation ahead of inflation, buried in the fine print are projections of sizeable reductions in extramural grants, and in many science and technology programmes at other agencies. For example, excluding the funding earmarked for refurbishing the NIH's on-campus hospital, its actual budget increase is only $1.3 \%$, well below the rate of inflation.

The closer one looks, the more dire the implications. Clinton administration largesse is targeted to the agencies that historically have funded the lowest quality and most applied research. For example, some of the largest proposed increases are for the Department of Commerce (up 16.9\%, to $\$ 4.3$ billion) and the EPA (up $22.8 \%$, to $\$ 7$ billion). In 1995 , the EPA was harshly criticized by a National Academy of Sciences panel for low scientific standards and lack of peer review of its research - problems that more money alone cannot solve.

Even without new funds, Clinton could easily adopt several no-cost strategies that would increase productivity. He could limit government support to highly meritorious projects that are unlikely to be undertaken by the private sector. He could craft incentives to increase private-sector participation in early stages of research. He could enhance the overall quality of governmentsponsored research by subjecting all proposals to a scientific peer-review process to ensure quality and merit. But none of these seems to have occurred to the president or his advisers.

Henry I. Miller

Hoover Institution \& Institute for

International Studies,

Stanford University,

Stanford, California 94305-6010, USA

e-mail: miller@hoover.stanford.edu

corres@nature.com

Letters submitted for Correspondence should be typed, double-spaced, on one side of the paper only, or e-mailed to corres@nature.com. 